\title{
O universo do grotesco e do monstruoso retratado no Ciclope de Eurípides e na Centauromaquia de Ovídio
}

Roberta Kelly Paiva

FALE-UFMG

betakelly2000@yahoo.com.br

RÉSUMÉ: Mikhail Bakhtin ${ }^{1}$ disait déjà à propos du corps grotesque: "[corps] monstrueux, horrible et déformé. C'est un corps qui n'a pas de place dans 'l'esthétique du beau'". Celle-ci est une des manières par lesquelles on peut comprendre cette autre esthétique connue comme celle du "grotesque", c'est-à-dire sous la perspective de la monstruosité. Et c'est exactement ce que nous proposons dans cet article: offrir un regard sur le grotesque et le monstrueux comme des domaines passibles d'être conçus sous une même et seule logique. Dans ce but, nous attirons l'attention sur quelques entités rustiques de la mythologie dont la représentation sera centrée sur deux oeuvres littéraires d'origine grecque et latine respectivement: le Cyclope d'Euripide et l'épisode de la "Centauromaquie" telle comme il est raconté dans les Métamorphoses d'Ovide.

MOTS-CLÉS: grotesque; monstrueux; mythologie; entités rustiques; hybridisme.

\section{O universo "rebaixado" da herança clássica}

A herança legada pelos clássicos à nossa era não se restringe necessariamente a um universo "clássico", na acepção bakhtiniana, ${ }^{2}$ ou seja, a uma estética que visa a projeção do sublime, do perfeito, do belo em sua máxima expressão. Seria o natural de se pensar diante das diversas imagens de deuses e heróis que têm seus grandiosos feitos aludidos pelos renomados poetas e tragediógrafos da Antiguidade. Contudo, não são apenas essas as imagens que figuram no pensamento mítico greco-latino.

Há que se lembrar de um outro rol de criaturas que se confundem entre aquelas e não se encaixam em uma classificação estrita. São elas consideradas entidades "secundárias" ou "menores", pois não possuem o mesmo status que as divindades. Esse relativo menosprezo advém de seu caráter híbrido e, de certo modo, monstruoso ou esdrúxulo, uma vez que apresentam traços tanto divinos quanto humanos ou, mais marcantemente, animalescos. Incluem-se entre tais entidades sátiros, centauros e ninfas.

Os sátiros (ou silenos) representam para os gregos demônios da Natureza. Seres híbridos (homens-bode), trazem dois traços marcantes: uma longa cauda equina e o membro viril de proporções anormais, sempre ereto. Amantes do vinho, da arte, da dança e da música e, sobretudo, do sexo, vivem a perambular pelos bosques à procura de parceiras, em geral, ninfas para saciar seu infindável desejo sexual. Riem do pavor

${ }^{1}$ Cf. Bakhtin, M. A cultura popular na Idade Média e no Renascimento. O contexto de François Rabelais. Tradução de Yara Frateschi Vieira. São Paulo: Hucitec, 2008, p. 26 (minha tradução do trecho citado para o francês).

${ }^{2}$ Cf. Bakhtin, op. cit. 
que lhes causa sua volúpia. Tais fatores, aliás, lhes permitem integrarem-se no lascivo cortejo de Dioniso, deus do hibridismo por excelência. ${ }^{3}$

No que se refere aos centauros, afiguram também criaturas duplas: meio humanas (parte superior) e meio equinas (parte inferior). Ao contrário dos sátiros, porém, possuem um porte grandioso, o que lhes acentua a aparência rude, violenta e grosseira. Dentre suas características inerentes estão uma forte propensão à embriaguez e ao sexo.

Frequentemente relacionadas a tais seres, as ninfas aparecem como mães ou amantes tanto de divindades quanto de entes mortais, ou mesmo de demônios (como os sátiros). Entidades femininas igualmente vistas como "secundárias" e habitantes dos campos e das águas, distinguem-se pelo dom da eterna juventude e pela estonteante beleza. Possuem, dessa maneira, além de uma longevidade sobrenatural, o poder da sedução.

Cegados por seu apetite, sempre exagerado, por comida, bebida e sexo, isto é, pelas necessidades mais materiais, os espíritos masculinos da Natureza - como os citados acima - guiam-se prioritariamente por seu desejo instintivo aguçado, não ponderando as possíveis consequências de suas ações. Devido a esse acentuado aspecto animalesco que compõe sua natureza, eles podem ser vistos pela ótica do grotesco. E levando-se em conta, dentre outros fatores, a hiperbolização de seus traços selvagens, podem ser encarados até mesmo sob a perspectiva do monstruoso, do esdrúxulo, ou seja, daquilo que é extravagante, que foge a qualquer padrão.

A essas entidades, mostra-se também associado um poder sobre-humano. Ele pode ser demonstrado pelos dons artísticos - como o da música e o da dança - e oraculares atribuídos aos sátiros, por exemplo, e pela ascendência divina que por vezes algumas dessas entidades apresentam. Desse modo, elas encerram em sua própria constituição um caráter profundamente ambivalente, marcado tanto pela vulgaridade de sua natureza agreste quanto por uma tendência à espiritualização.

A caracterização peculiar desses seres rústicos, que não se deixam apreender por nenhuma categorização rígida - pois não podem ser puramente definidos como homens nem animais e muito menos deuses -, transparece nas obras que constituem objeto deste

\footnotetext{
${ }^{3}$ Deus do Vinho e da Loucura, Dioniso (Baco, para os romanos) incorpora a personalidade divina mais versátil, sendo percebido simultaneamente como homem e animal, másculo e efeminado, jovem e velho. A ele são associados os prazeres carnais - tais quais o da sexualidade e da embriaguez - mas também dons artísticos como o da música e da dança.
} 
estudo. Com efeito, tanto no Ciclope, um drama satírico, quanto no episódio da luta dos centauros reproduzido por Ovídio percebe-se a exageração típica da fisionomia e do comportamento de tais criaturas, as quais chegam a assumir uma feição caricaturesca. Até as histórias em si são impregnadas por essa tendência hiperbólica, que contamina todo o seu desdobramento. Além disso percebe-se, por um outro ângulo, o caráter dual expresso por essas criaturas e, mais uma vez, pelas tramas que as tematizam. Portanto, a ambivalência que compõe a natureza daquelas pode ser igualmente identificada, em um nível mais amplo, nestas.

\section{O grotesco e o monstruoso sob a mesma luz}

A fim de compreendermos um pouco melhor a lógica pela qual será examinado o universo de ambas as histórias convém antes, porém, passar em revista algumas noções envolvidas pelos domínios do grotesco e do monstruoso. No que concerne ao primeiro destes, tomemos como base o relevante estudo empreendido por Bakhtin ${ }^{4}$ acerca da cultura popular e suas origens, visto que as formulações nele lançadas pelo teórico parecem muito bem aplicáveis às figurações das entidades mitológicas que ora são discutidas. Nele o pensador moderno chamou atenção para certas questões que permaneciam até então meio adormecidas dentro do campo da crítica literária. Foi o caso da "rivalidade" (se assim pode ser concebida) entre o que ele nomeou de "cânone grotesco" e "cânone clássico".

Interessado na disparidade entre esses dois gêneros canônicos, o crítico russo pensou tal problemática em termos de uma complementaridade; ambos se integrariam na história literária: o alto - relacionado ao sublime e identificado como clássico - e o baixo - relacionado ao vulgar e identificado como grotesco. Todavia, Bakhtin ${ }^{5}$ argumenta em favor da riqueza desse último, o qual, segundo ele, consegue sintetizar, em seu seio, a mistura do nobre e do vil. Tal miscelânea, sob o ponto de vista do teórico, consiste em uma das marcas desse gênero, cujas imagens resistem a ajustar-se ao cânone clássico (exatamente como as imagens que nos chegam dos seres rústicos da mitologia).

Ao discorrer sobre esse gênero oposto ao clássico, Bakhtin ${ }^{6}$ ressalta alguns fatores que, a seu ver, são-lhe intrínsecos. Dentre eles estão a comicidade (encarnada

\footnotetext{
${ }^{4}$ Cf. Bakhtin, op. cit.

${ }^{5} \mathrm{Cf}$. Bakhtin, op. cit.

${ }^{6} \mathrm{Cf}$. Bakhtin, op. cit.
} 
por um riso dessacralizante e escancarado), o rebaixamento e, derivado deste, um potencial de ressurgimento, todos envoltos por uma ambivalência fundamental. Eles sintetizariam uma visão de mundo que o teórico denomina como carnavalesca (por ser festiva, popularizante, coletivizadora), núcleo da cultura popular, incorporando ideais de universalidade, liberdade e abundância (expressa, por exemplo, pelo hiperbolismo de certos aspectos de suas figuras).

Desses fatores que estruturam o domínio do grotesco muito se relaciona também ao domínio do monstruoso. De início, percebemos que ambos são identificados como diretamente interligados a uma "estética do feio", tendo em vista sua clara oposição a uma estética do sublime que busca a projeção do belo pelo perfeito enquadramento no modelo canônico clássico, conforme Bakhtin. ${ }^{7}$ Ademais, a ambivalência essencial que fundamenta o grotesco e sua tendência à universalidade e à abundância são igualmente intrínsecas ao monstruoso, traduzindo-se por um hibridismo reinante e um extravasamento hiperbólico que rejeita a imposição de limites ou de qualquer padronização. Nas palavras do teórico russo, cujo conteúdo é extensível à esfera da monstruosidade,

as imagens grotescas conservam uma natureza original, diferenciamse claramente das imagens da vida cotidiana, preestabelecidas e perfeitas. São imagens ambivalentes e contraditórias que parecem disformes, monstruosas e horrendas, se consideradas do ponto de vista da estética "clássica", isto é, da estética da vida cotidiana preestabelecida e completa.

De acordo com a etimologia do termo monstrum em latim, derivado dos verbos monstrare ("mostrar", “indicar") ou monere (“avisar", "advertir"), ele era usado inicialmente pelos romanos para indicar um prodígio, um fato sobrenatural, estranho ao mundo humano. Designava uma espécie de sinal enviado aos homens para "mostrar" a reação dos deuses diante de seus atos. Nessa acepção, o termo não tinha necessariamente uma conotação negativa, exatamente como o sentido original reclamado por Bakhtin ${ }^{9}$ para o grotesco, o qual, segundo ele, nunca era totalmente negativo, guardando também um lado positivo.

Da mesma forma, o campo semântico do monstruoso para os gregos antigos não

\footnotetext{
${ }^{7}$ Cf. Bakhtin, op. cit.

${ }^{8}$ Cf. Bakhtin, op. cit., p. 22 (grifo do autor).

${ }^{9}$ Cf. Bakhtin, op. cit.
} 
se restringia forçosamente a uma conotação negativa, podendo indicar, por vezes, um fato positivo, mas que não deixava de parecer estranho ou extraordinário aos olhos

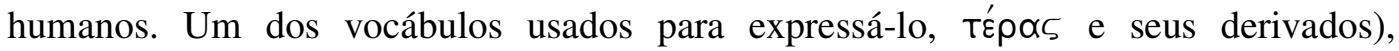
designava justamente algo maravilhoso, espantoso, que era interpretado como um prodígio, um presságio ou um sinal dos deuses aos homens, tal qual concebido pelos latinos.

Com o tempo, esse sentido inicial conferido à palavra "monstro" e correlatas na Antiguidade foi modificando-se. Seu senso religioso de revelação divina foi-se perdendo e dando lugar apenas à noção de estranheza. Foi, em linhas gerais, assim que o termo monstrum, na literatura latina, foi deixando a acepção de prodígio ou sinal divino encarnado por um ser disforme - em que a ideia de deformidade já é flagrante, como também podia ser incorporada pelo vocábulo grego Tépas - para gradativamente assimilar a de um fenômeno mítico (fantasioso), temível (porque danoso, nocivo) ou cruel. Logo, nota-se que de um sentido indefinido, o qual podia pender tanto para o lado positivo quanto para o negativo, o domínio lexical denotativo da monstruosidade foi adquirindo para os antigos uma compreensão puramente negativa. Todavia, é na ambiguidade de seu entendimento primitivo que o grotesco, em suas manifestações originais, encontra maior ressonância.

Essa ambiguidade ou esse hibridismo que se encontra na base do monstruoso advém da sua recusa a se prender a uma classificação ou a se deixar regular por qualquer normalização. Efetivamente, seu âmbito próprio é o do limiar, das margens, do entrelugar, situando-se ao mesmo tempo em diversos espaços e em nenhum em específico. É o que pondera Jeffrey Cohen ao denominar o monstro como "o arauto da crise de categorias":

O monstro sempre escapa porque ele não se presta à categorização fácil. (...) Essa recusa a fazer parte da "ordem classificatória das coisas" vale para os monstros em geral: eles são híbridos que perturbam, híbridos cujos corpos externamente incoerentes resistem a tentativas para incluí-los em qualquer estruturação sistemática. E, assim, o monstro é perigoso, uma forma - suspensa entre formas que ameaça explodir toda e qualquer distinção. ${ }^{10}$

\footnotetext{
${ }^{10}$ Cf. Cohen, J. J. A cultura dos monstros: sete teses. In: da Silva, T. T. (org.). Pedagogia dos monstros. Os prazeres e os perigos da confusão de fronteiras. Belo Horizonte: Autêntica, 2000, p. 30.
} 
Jenny Clay, ${ }^{11}$ ao abordar a monstruosidade conforme exposta especificamente na obra de Hesíodo, aponta ainda outros fatores que lhe são igualmente conexos. É o caso da anomalia ou deformidade bastante recorrente nas representações dos monstros (não apenas entre os gregos mas também entre os latinos), devido à sua propensão de reunir, em uma única criatura, aspectos completamente díspares, enquanto reflexo de sua natureza híbrida. Além disso, da sua fuga aos padrões ou a uma categorização estrita provém uma tendência à transgressão de barreiras, à desmedida, à multiplicação de traços, à enormidade, enfim - semelhantemente à tendência à universalização destacada por Bakhtin $^{12}$ em relação ao grotesco. Dessa tendência deriva, por sua vez, a incapacidade humana de controle de todas as monstrificações, pois a desordem e a total insubordinação constituem seu meio mais familiar. É o que pode ser identificado também na esfera do grotesco, própria "expressão da desordem”, segundo Cláudio Aquati, e cujo "caráter heterogêneo fundamental (...) se traduz numa desarmonia". ${ }^{13}$

\section{Reflexos do grotesco/ monstruoso em Eurípides e Ovídio}

Levando-se em consideração as diversas noções englobadas nos campos do grotesco e do monstruoso - várias das quais se imbricam umas nas outras - torna-se possível compreender a influência desses campos nas duas obras literárias aqui propostas para discussão. Tanto a peça de Eurípides quanto o recorte em foco das Metamorfoses de Ovídio são construídos, conforme será demonstrado adiante, com base em um hibridismo que envolve a própria trama como um todo e as personagens que a compõem em particular, dentre os quais se destacam os sátiros (para a primeira) e os centauros (para o segundo). Desse hibridismo estruturante surgem outros aspectos que afetam ambas as histórias, tais como a rejeição de limites, a tendência à proliferação geral ou à desmedida e a manifestação de um universo em conflito, em profunda desarmonia. Ademais, tais aspectos sugerem alguns pólos opositivos pertinentes à análise desse universo presente nas mesmas: ordem versus desordem, limitação versus transgressão ou regulação versus liberdade, humano versus animal. Todas essas possibilidades permitem, por consequência, abordar ambas as obras sob uma mesma perspectiva do grotesco/ monstruoso.

\footnotetext{
${ }^{11}$ Cf. Clay, J. S. Hybrids. In: Hesiod's cosmos. Cambridge: University Press, 2006. p. 150174.

${ }^{12}$ Cf. Bakhtin, op. cit.

${ }^{13} \mathrm{Cf}$. Aquati, C. O grotesco. In:

27 (tese de doutorado em letras clássicas).
} 


\section{nuntius antiquus}

O Ciclope, escrito, conforme se acredita, antes de 425 a.C., é o único drama satírico que pôde ser recuperado integralmente na contemporaneidade. Por isso, é testemunho singular, capaz de demonstrar como se compunha esse gênero dramático na Antiguidade. Tal gênero, situado nos primórdios da arte teatral grega, era dedicado, como a Tragédia, ao deus Dioniso. Contudo, esta tornou-se mais política (e política no sentido de exclusiva do mundo da pólis) à medida que foi-se ocupando dos mitos heroicos próprios da Épica, ao passo que o Drama Satírico conservou claramente a força dionisíaca animal e primitiva graças à presença obrigatória dos sátiros (companheiros do deus do Vinho) no seu coro. Estes lhe conferiram a mistura entre o sério e o bufo, o que colocou esse gênero dramático entre a Tragédia (pela nobreza das mesmas personagens heroicas) e a Comédia (pela presença do riso malicioso e alegre dos sátiros e de sua licenciosidade natural).

Para compor seu drama, Eurípides se baseou no episódio do Canto IX da Odisseia em que Ulisses, retornando do árduo combate em Troia, vê-se desviado de sua rota de volta para Ítaca e, com seus companheiros, desembarca na ilha dos ciclopes. Estes, já em Homero, são descritos como criaturas gigantescas e monstruosas que possuem apenas um olho no meio da testa. No desfecho da narrativa é cumprida a profecia segundo a qual o chefe dessa raça abominável, Polifemo, seria cegado por Odisseu. Assim também se desenrola a trama euripidiana; porém, ela sofreu algumas modificações com o fim de se adaptar à representação cênica e, sobretudo, de incluir um coro jocoso como o dos sátiros.

A peça inicia-se com o desembarque de Odisseu e sua tripulação na ilha da Sicília, aos pés do Etna, para onde são lançados por fortes tempestades marítimas. Esse foi o reduto escolhido pelo dramaturgo para situar sua ação, já que a lenda hesiódica identificava-o como esconderijo das forjas de Hefesto (deus do Fogo), para o qual trabalhavam os ciclopes, artífices dos raios de Zeus. A partir de então, toda a encenação gira em torno dos protagonistas: o herói da Odisseia, Sileno (pai dos sátiros) e o monstro Polifemo, rodeados pelo coro satírico.

Os gigantes de um olho só são pintados por Eurípides como seres horrendos, disformes e incrivelmente brutos, de natureza selvagem e inclusive canibalesca. Polifemo, em especial, filho de uma ninfa com o deus dos mares Poseidon, é retratado em toda a sua desmedida: tanto sua composição física quanto seus hábitos (alimentares, por exemplo) são marcados pelo extremo exagero, além de seu despeito pelos outros 
deuses (até por Zeus) levá-lo a blasfemar irresponsavelmente contra eles. Tal comportamento ensoberbecido pela üßpıs a desmedida, o excesso, a insolência) pode ser exemplificado por este pequeno trecho: "La foudre de Zeus ne me fait pas peur, étranger, et j'ignore en quoi Zeus est dieu supérieur à moi”. ${ }^{14}$ Tais características associadas à raça dos ciclopes já demonstram o quão monstruosa e grotesca ela se apresenta.

Após a chegada dos gregos vitoriosos à terra dos gigantes, Sileno é o primeiro que os interpela. Abrindo a peça em uma espécie de prólogo, e seguido pelo coro de seus filhos, ele expõe sua situação atual e a desventura que a causou quando, ao navegarem à procura de Dioniso raptado, foram arrastados por uma tormenta até a Sicília e aprisionados por Polifemo como escravos. Conhecendo a necessidade da tripulação de obter alimento para saciar a fome, o pai dos sátiros propõe a Odisseu trocar o vinho que este trazia pelo repasto do monstro, que se encontrava longe. No entanto, no decorrer da negociação Polifemo aproxima-se e surpreende-os. A partir desse momento constata-se a covardia do velho Sileno diante de seu senhor execrável e a fragilidade de seu caráter, que oscila despudoradamente de acordo com sua conveniência. Por outro lado, percebe-se que o herói épico mantém sua nobre postura mesmo fora do domínio sério da Epopeia ou da Tragédia.

A peça se desenrola então de forma similar à narrativa homérica, em meio às ameaças e extravagâncias do ciclope, às lamentações e covardias dos sátiros e seu impotente pai e aos planos ardilosos de Ulisses para vingar-se do gigante que devorara dois de seus companheiros em uma só refeição. E ao final, como no desfecho do relato da Odisseia, o herói consegue cumprir seu estratagema e cegar o monstro. Em seguida, escapa da ilha com seus companheiros resgatando ainda os sátiros. Portanto, a história recebe um termo feliz, como era usual nas tetralogias (sequência de três tragédias e um drama satírico, conforme eram encenados na Grécia Antiga).

$\mathrm{O}$ ar alegre e cômico de toda a trama é uma consequência da introdução da presença dos espíritos baixos da mitologia em um episódio lendário originalmente sério e elevado. De fato, o herói épico ou trágico - que estava inserido em um contexto grave, conflituoso e sempre nobre, devido à importância de seu papel - vê-se imerso em um

\footnotetext{
${ }^{14}$ Cf. Euripide. Le Cyclope. Texte établi et traduit par Louis Méridier. Paris: Les Belles Lettres, 1947. Tome I, v. 320-321 (todas as traduções francesas de Eurípides provêm, neste texto, dessa edição de Les Belles Lettres).
} 
drama satírico como o Ciclope: em uma atmosfera profundamente contaminada por uma jocosidade dessacralizante e por uma tendência ao rebaixamento propriamente material, reflexo nítido da influência dionisíaca. Logo, o contexto da ação heroica muda, mas o caráter de Ulisses em Eurípides permanece bem próximo daquele que se tem na Odisseia, digno e corajoso.

Ao ser traído por Sileno, por exemplo, que o acusa diante de Polifemo inventando mentiras das mais descabidas para safar-se da culpa de negociar seus bens com o estrangeiro, este age conforme os costumes de sua civilização, requisitando ao gigante os dons da hospitalidade. Conforme ressaltam Simmonds e Timberlake, ${ }^{15}$ Odisseu conserva incorruptível seu espírito guerreiro e aventureiro, bravo em face dos perigos. Já os sátiros, ao contrário, demonstram toda a sua covardia e vulnerabilidade ao descumprirem, por medo, a promessa antes feita ao herói de ajudá-lo a executar seu plano de cegar o monstro. Desse modo torna-se clara a dicotomia criada na peça entre o que é sério, nobre e estável e o que é burlesco, vulgar e completamente instável.

Uma outra diferença entre os personagens aparece no plano da linguagem. Ainda de acordo com Simmonds e Timberlake, ${ }^{16}$ o tom discursivo empregado por Ulisses ao longo do enredo é perfeitamente conciliável ao estilo elevado da Tragédia. Além disso, conforme destaca Judith Fletcher ${ }^{17}$ ao tratar do uso da linguagem nessa peça de Eurípides, o herói detém o controle sobre seu discurso e, consequentemente, pode garantir o sucesso de suas ações, uma vez que sabe invocar adequadamente os deuses e conquistar seus favores pela sua habilidade oratória. Ele lhes é reverente e mostra-se temente em relação a seu poder soberano. Tal astúcia discursiva pode ser notada pelo seguinte trecho, em que Odisseu invoca o auxílio dos deuses para efetivar sua vingança contra o ciclope:

Héphaistos, seigneur de l'Etna! D'un voisin pervers, en incendiant la clarté de son oeil, délivre-toi d'un coup! Et toi, rejeton de la sombre Nuit, Sommeil, dans toute ta force abats-toi sur la bête abhorrée des dieux! Après les glorieux travaux de Troie, ne livrez pas, avec ses matelots, Ulysse aux coups d'un homme qui n'a cure des dieux ni des mortels. Sinon, il faut tenir le hasard pour un dieu, et le pouvoir des dieux pour moins que le hasard! ${ }^{18}$

${ }^{15}$ Cf. Euripides. The Cyclops. Edited by D. M. Simmonds and R. R. Timberlake. London: Bristol Classical Press, 1997.

${ }^{16}$ Cf. Euripides, op. cit.

${ }^{17}$ Cf. Fletcher, J. Perjury and the perversion of language in Euripides' “Cyclops”. In: Harrison, G. W. M. (org.). Satyr drama. Tragedy at play. Swansea: The Classical Press of Wales, 2005, p. 53-66.

${ }^{18}$ Cf. Euripide, op. cit., v. 599-607. 


\section{nuntius antiquus}

O mesmo não se pode dizer, todavia, desse uso performativo da linguagem feito pelos outros dois protagonistas que, não por acaso, não são totalmente humanos. Como comentado anteriormente a respeito do emprego abusivo e destemido da linguagem pelo gigante, Sileno também apresenta um discurso inconsequente e desrespeitoso perante os deuses. Ambos comportam-se de maneira indecorosa e ímpia, cegados pela üßpıs, e utilizam uma linguagem profana - o primeiro por orgulho e pela arrogância de achar-se um deus (até mais poderoso que os demais) e o segundo pela imprudência e estupidez, o que o torna mais cômico. Essa desmedida expressa pelo discurso é ilustrada, por exemplo, pela passagem em que o pai dos sátiros, surpreendido por Polifemo a entregar seus bens a Ulisses, implora-lhe que acredite que ele foi vítima do estrangeiro recém-chegado:

Par Poseidon, l'auteur de tes jours, ô Cyclope, par le grand riton et par Nérée, par Calypso et par les Néréides, par les flots sacrés et par la race des poissons tout entière! J'en fais le serment, ô le plus beau de tous, mignon Cyclope, non, mon cher petit maitre, je ne vendais pas ton bien à des étrangers. Sinon, (montrant les satyres) périssent de malemort ces enfants que je chéris tant! ${ }^{19}$

Todas essas ambiguidades que contrapõem os personagens do drama euripidiano entre si constituem, no fundo, manifestações do grotesco e do monstruoso tais quais eram concebidos na Antiguidade. A ambivalência essencial desse gênero, conforme alega Bakhtin, ${ }^{20}$ e que se traduz no hibridismo típico do monstruoso circunda, além dos próprios personagens, toda a atmosfera da história. Ela se mostra, de início, na caracterização destes: o ciclope é identificado como pertencente a uma raça de gigantes mas também a uma estirpe divina, vangloriando-se de ser filho de um deus; os sátiros e seu pai Sileno, além de seguidores de um deus (Dioniso), possuem traços que os qualificam tanto como humanos quanto como animais; e Odisseu, apesar de ter forma humana, na sua condição de herói incondicional assemelha-se à linhagem divina, sobretudo pela sua nobreza de caráter e pela sua coragem e astúcia diante dos perigos.

Entretanto, ultrapassando esse plano particular, podemos observar que a mesma ambivalência compõe a lógica global do enredo, pois seu universo é, acima de tudo, conflitante. Enquanto a desordem e a instabilidade reinam entre as criaturas baixas do drama, a ordem e a firmeza pautam a ação do herói, que tenta organizar esse mundo

\footnotetext{
${ }^{19}$ Cf. Euripide, op. cit., v. 262-270.

${ }^{20} \mathrm{Cf}$. Bakhtin, op. cit.
} 
caótico punindo o gigante pela sua desmedida e restituindo a família dos sátiros ao seu posto original (no rastro de seu mestre, o deus da desordem por natureza). ${ }^{21}$ Essa oposição entre ordem - domínio dos heróis - e desordem - domínio dos monstros -, conforme aborda Clay $^{22}$ ao tratar do cosmos hesiódico, deflagra um importante aspecto do grotesco/ monstruoso.

Além dessa dicotomia, outras pertencentes ao mesmo campo do grotesco/ monstruoso são percebidas ao longo da peça, conforme já indicamos. O tom sério trazido pelo elemento heroico opõe-se ao tom jocoso inerente ao caráter dos sátiros. $\mathrm{O}$ riso carnavalesco (porque contagiante), segundo a concepção bakhtiniana, afeta até a imagem do próprio ciclope que, deixando-se levar pelos conselhos distorcidos de Sileno, acaba embriagado como ele e ainda cegado por Ulisses, sendo tripudiado pelos sátiros e, por consequência, exposto ao ridículo. Contudo, esse riso faceiro e alvoroçado pode expressar-se também como libertino e malicioso, ligando-se ao erotismo que Eurípides incute na linguagem de seus personagens e que aponta, por sua vez, para o baixo corporal. ${ }^{23}$ Este, voltado para os prazeres da carne (com destaque para órgãos como o membro viril, o ventre e a boca escancarada), expressa, de acordo com Bakhtin, ${ }^{24}$ o grotesco em toda a sua pureza.

$\mathrm{E}$, dessa licenciosidade que contamina o clima da trama, juntamente com a tendência à desmedida e à extravagância, advêm o hiperbolismo de suas figuras e a transgressão dos limites. Isso pode ser exemplificado pelas dimensões exageradas dos órgãos baixos dos sátiros e do gigante e das refeições deste. Essas, assimiláveis às imagens grotescas de banquete discutidas pelo teórico russo, ${ }^{25}$ ilustram igualmente a tendência típica da monstruosidade à abundância, à proliferação, à universalidade. Finalmente, toda essa libertinagem e esbanjamento contrapõem-se às normas e modelos impostos à sociedade que regulam qualquer civilização, cujo representante máximo na peça encarna-se na figura de Odisseu, elemento que visa trazer a ordem a esse mundo desregrado do grotesco/ monstruoso. Não é sem propósito que tal mundo seja

\footnotetext{
21 Odisseu parece até ter sido enviado pelos deuses à terra dos ciclopes para cumprir essa função, concretizando também a profecia de que ele cegaria Polifemo. Como afirma Clay (op. cit., p. 150): While the monsters come into being spontaneously in their exuberant disorder, the heroes are the products of a distinctive divine intervention that momentarily blurs the boundaries between gods and men.

${ }^{22}$ Cf. Clay, op. cit.

${ }^{23}$ A respeito do uso de uma dicção erótica e toda sua influência no drama Ciclope, cf. Slenders, W.

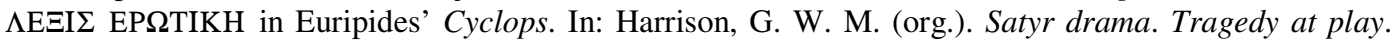
Swansea: The Classical Press of Wales, 2005. p. 39-52.

${ }^{24}$ Cf. Bakhtin, op. cit.

${ }^{25}$ Cf. Bakhtin, op. cit.
} 
ambientado em um lugar tão hostil à fixação de uma população - em uma ilha e bem aos pés do Etna -, ou seja, distante das civilizações (como é comum nas representações do monstruoso).

Várias das características anteriormente aludidas sobre o drama satírico euripidiano que evocam a lógica do grotesco e do monstruoso sob o ponto de vista dos antigos podem ser igualmente levantadas nas Metamorfoses de Ovídio. Compondo um “discurso de maravilhas", segundo expressão utilizada por Elaine Fantham, ${ }^{26}$ essa obra - supostamente escrita na transição para a era cristã e publicada originalmente por volta do ano 8 d.C. - consiste em uma extensa narrativa (em versos) fragmentária envolvendo histórias lendárias e personagens diversificadas. Foi produzida por Ovídio como uma espécie de relato mítico do mundo, com o suposto fim de explanar a origem e as causas dos diferentes fenômenos e acontecimentos que acometem a vida do homem. Esse seu cunho fragmentário e fantasioso já lhe confere um aspecto monstruoso, pelo hibridismo nela incorporado e por evocar variados mitos (lembrando um dos sentidos que os latinos atribuíam à palavra monstrum relacionado à fantasia, ao que é irreal).

Particularmente quanto ao episódio aqui focalizado - a Centauromaquia -, localizado no Livro XII, trata-se de uma digressão na narrativa que coloca em pauta, nos dizeres de Fantham, ${ }^{27}$ "criaturas fabulosas, a raça dos centauros". Nesse livro das Metamorfoses, situado na parte da composição dedicada aos líderes "históricos" dentre os quais os fundadores de Roma como Eneias, o herói de Virgílio -, o assunto gira em torno de lendas sobre a guerra de Troia. Quem assume o papel de principal narrador dessas fábulas é o velho Nestor, também personagem de Homero, reconhecido como sábio devido à sua longa experiência de vida, inclusive por ter participado de grandes batalhas, como a que serve de tema central à Ilíada.

Contudo, são sempre introduzidas interrupções ao relato do combate troiano que, na interpretação de Margaret Musgrove, ${ }^{28}$ funcionam como um contraste geral à sequência da narrativa épica, pois ora deslizam para o gênero trágico, ora para o pastoril. Aparentemente a exposição da Centauromaquia enquadrar-se-ia em um desses casos. No entanto, essa longa digressão feita por Nestor para descrever uma peleja que

\footnotetext{
${ }^{26} \mathrm{Cf}$. Fantham, E. Fantasy, the fabulous and the miraculous: metamorphoses of nature. In: Ovid's “Metamorphoses”. Oxford: University Press, 2004, p. 106 (minha tradução).

${ }^{27}$ Cf. Fantham, op. cit., p. 106 (minha tradução).

${ }^{28}$ Cf. Musgrove, M. W. Nestor's Centauromachy and the deceptive voice of poetic memory (Ovid Met. 12.182-535). Classical philology. Chicago, vol. XCIII, n. 3, p. 223-231 (disponível em: <http://www.jstor.org/stable/270542> acesso em 30 de setembro de 2008).
} 
teria ocorrido duzentos anos antes da destruição de Troia pelos gregos não serviria apenas para mostrar uma transição de gêneros - até porque a forma épica tradicional persiste em seu relato. Na visão da mesma autora, sua relevância se explica antes pelos questionamentos que tal procedimento é capaz de suscitar acerca da legitimidade de uma narrativa épica e do grau de confiabilidade que se pode atribuir a seus narradores levando-se em conta todo o hiperbolismo conferido à exposição desse episódio em Ovídio, conforme comentaremos.

O relato de Nestor, dirigido aos que vieram depois da guerra de Troia, retrocede duas centenas de anos a esse combate, quando os pais dos heróis que nele lutaram inclusive ele mesmo - estavam no auge da juventude. Refere-se a outra batalha, bem anterior à troiana, que ocorrera entre o povo dos lápitas e a tribo dos centauros. Dela ele assegura ter participado: "Les chefs de l'Hémonie étaient là; j’y étais moi-même". ${ }^{29}$

Era ocasião do casamento entre Pirítoo, príncipe lápita, e Hipodâmia, uma bela virgem. O noivo havia convidado os selvagens centauros para participarem das solenidades. Entretanto, no meio da festa, o mais valente desses seres de dupla natureza, Eurito, já embriagado pelo vinho e enlouquecido pelos encantos da noiva, no seu furor resolve raptá-la. E assim o fazem também seus iguais, cada qual violentando a virgem que mais the agradasse. Esse assalto inesperado causa tamanho transtorno entre os convivas que desencadeia uma gigantesca e sangrenta batalha, da qual os heróis gregos ali presentes tomam parte ao lado do noivo ultrajado.

Como uma enumeração das ferozes lutas entre os adversários e das vítimas que delas iam resultando prossegue a narrativa de Nestor. Seu discurso se desenrola sobre o estilo épico tradicional, porém incorpora, ainda que sutilmente, um certo tom cômico, que o torna similar a uma paródia da epopeia canônica tal qual a de Homero ou Virgílio. Efetivamente, conforme sinaliza Musgrove, ${ }^{30}$ o velho narrador de Ovídio - igualmente personagem homérico - constrói um imenso catálogo de nomes e fatos que atravessa séculos apenas contando com sua própria memória, sem nem mesmo invocar a assistência das Musas, como tradicionalmente feito pelos poetas. Aliás, é de se notar a inverossimilhança de seu relato, o qual se pauta em um flashback em primeira pessoa, que demonstra a impossibilidade de esse narrador retratar fielmente os acontecimentos

${ }^{29}$ Cf. Ovide. Les Métamorphoses. Texte établi et traduit par Georges Lafaye. Paris: Les Belles Lettres, 1957. Tome III, livre XII, v. 213-214 (todas as traduções francesas de Ovídio provêm, neste texto, dessa edição de Les Belles Lettres).

${ }^{30} \mathrm{Cf}$. Musgrove, op. cit. 
(que também o envolveram ativamente) como se fosse um narrador onisciente. Logo, de acordo com a opinião da autora, a distância do passado por ele evocado e o recurso unicamente de sua memória, a de um simples mortal, problematizam a legitimidade de seu testemunho e colocam em dúvida sua autoridade, bem como a dos narradores épicos em geral, o que não deixa de parodiar os grandes textos canônicos.

O tom cômico da digressão não permanece somente no discurso de Nestor, mas estende-se ao exagero com que ele pinta o episódio. As disputas entre os opositores são hiperbolizadas de tal maneira que chegam a parecer engraçadas. As armas por eles utilizadas são todas improvisadas a partir dos próprios instrumentais do recinto (que se situava em um antro escondido dentro de um bosque) e do ambiente natural que o circundava - como tochas e castiçais acesos, altares e até mesmo árvores inteiras arrancadas ao solo e lançadas violentamente uns contra os outros. E os desastres que se sucedem são descritos de modo tão detalhado, os golpes trocados pelos combatentes aparentam tão truculentos que as cenas referidas afiguram-se repugnantes. Haja vista este trecho:

Il se fait une arme d'un bois de cerf, offrande votive exposée au sommet d'un pin. Il enfonce les deux cornes dans les orbites de Grynée et lui arrache les yeux; l'un demeure fixé à une des cornes; l'autre roule sur la barbe, où le sang coagulé qui l'entoure le retient suspendu. ${ }^{31}$

Todo esse exagero na reprodução da batalha, inclusive o fato de Nestor não diferenciar os humanos dos que eram semi-humanos e semi-animais - já que ambos os lados equivaliam-se em força e imponência -, para o quê chama atenção Fantham, ${ }^{32}$ serve como fonte de humor para Ovídio.

De fato, a impressão causada pelo relato não poderia ser diferente, devido à própria natureza das personagens envolvidas: de um lado, um povo rude ao qual se aliam heróis e, de outro, um bando de criaturas selvagens cujo porte se assemelha ao de gigantes. Isto é, atributos como coragem, vigor e arrogância não faltavam a nenhum dos lados. Ademais, o agravante do estado de embriaguez dos centauros, que não sabiam se controlar diante da sedução oferecida pelo vinho (tais quais os sátiros), reduplicava sua coragem e também sua estupidez. Assim, a luta toma proporções enormes e sua violência é exacerbada. Disso já resultam, pois, dois traços marcantes do grotesco: o

\footnotetext{
${ }^{31}$ Cf. Ovide, op. cit., livre XII, v. 265-270.
}

${ }^{32}$ Cf. Fantham, op. cit., p. 109. 
excesso e a extrapolação de limites (que caracterizam igualmente o monstruoso), acompanhados da comicidade. A cena do rapto da noiva é um bom exemplo dessa desmedida e de suas consequências desastrosas:

Car ton coeur, ô Eurytus, le plus sauvage des sauvages centaures, échauffé par le vin, s'enflamme encore à la vue de la jeune fille et le désir s'ajoute en toi aux fureurs de l'ivresse. En un instnat tout est en désordre dans le festin; les table sont renversées et la nouvelle épouse est traînée brutalement par les cheveux. Comme Eurytus ravit Hippodamé, chaque centaure ravit celle qui lui plaît e comme il peut; on aurait cru voir une ville prise d'assaut. ${ }^{33}$

Há ainda uma particularidade nesse episódio da Centauromaquia que lhe confere um efeito todo especial: dentro da longa digressão feita por Nestor, e que interrompe o relato das lendas troianas, surge uma outra digressão para expor um romance entre dois centauros que se diferenciam dos demais da sua raça. Em uma espécie de apóstrofe à continuação do seu catálogo de ataques entre centauros e lápitas, o narrador ovidiano lamenta a perda de Cílaro e Hilonômia, introduzindo uma história de amor entre ambos. Seres igualmente híbridos como seus irmãos, esses dois centauros possuíam, todavia, um caráter diversificado. Não eram naturalmente violentos e grosseiros como os outros, mas delicados, sensíveis e, apesar de sua composição semi-animalesca, descritos como belos. Formavam, desse modo, o par perfeito.

Por isso, estavam sempre unidos, faziam tudo juntos e, inclusive, compareceram juntamente à cerimônia do himeneu de Pirítoo e Hipodâmia. No alvoroço da batalha, tomaram ambos parte, lado a lado, da selvageria incitada por seus pares mas, em um momento inesperado, viram-se separados pela morte precoce de Cílaro, ferido por um golpe fatal. Hilonômia então, no desespero de sua dor, lança-se sobre a arma que traspassara seu amado e eles concluem, assim, seu enlace nupcial não em vida, mas na morte.

Essa interessante interposição de uma história aparentemente desconexa da narrativa maior não aparece por acaso no episódio. Conforme alerta Jeri DeBrouhun ${ }^{34}$ em um esclarecedor estudo especificamente sobre essa passagem da Centauromaquia, Ovídio explora variados sentidos dela derivados que enriquecem a narrativa de Nestor,

\footnotetext{
${ }^{33}$ Cf. Ovide, op. cit., livre XII, v. 218-226.

${ }^{34}$ Cf. DeBrohun, J. B. Centaurs in love and war. Cyllarus and Hylonome in Ovid "Metamorphoses" 12.393-428. American journal of philology. Baltimore, vol. CXXV, n. 3, p. 417-452, 2004 (disponível em: <http://muse.jhu.edu> acesso em 30 de setembro de 2008).
} 
bem como ampliam suas possibilidades interpretativas. Um desses sentidos, flagrante ao longo de toda a digressão maior e aguçado por essa digressão menor (que funciona como mise en abyme), é o do hibridismo grotesco/ monstruoso.

Esse fator que fundamenta a lógica da monstruosidade e expressa a ambivalência essencial grotesca faz-se presente inicialmente no recorte em foco da obra ovidiana pela própria composição dos principais personagens envolvidos: em um extremo, os heróis se acham na fronteira entre os planos divino e humano; no outro, os centauros se veem divididos entre as naturezas humana e animal. A partir do momento em que é introduzida a história do par romântico e que depois do seu desfecho ela dá lugar novamente ao mesmo relato da luta sangrenta em curso possibilita-se um aprofundamento desse sentido. Se os dois centauros amantes diferem tanto dos restantes é porque seu caráter aproxima-se mais da natureza humana, que neles se sobressai, enquanto nos outros o que fala mais alto é sua natureza animalesca. Isso explica a acentuada vulnerabilidade destes ao baixo material (por isso são atraídos pela bebida e pelo coito, por exemplo) e a tendência à ascensão espiritual do casal, que valoriza sentimentos nobres do homem como o amor e a união incondicional.

Finalmente, em um nível mais geral e em concordância com DeBrouhun, ${ }^{35}$ pode-se pensar que o quadro da Centauromaquia é em si mesmo híbrido e, logo, grotesco e monstruoso, uma vez que apresenta no decorrer de uma narrativa épica um interlúdio lírico-elegíaco. Portanto, ele acaba por consistir em uma mistura de personalidades e até mesmo de gêneros. Não se limita, para tomar de empréstimo os termos bakhtinianos relativos ao grotesco, a nenhuma "formalidade unilateral", a nenhuma "perfeição definitiva", a nenhuma "estabilidade" ou "formalidade limitada". 36 Afinal, o que prevalece nesse episódio ricamente elaborado por Ovídio é justamente a instabilidade e a mutação, razão pela qual ele faz parte das Metamorfoses. E uma das metamorfoses que talvez possam melhor sintetizá-lo, e igualmente ambígua, é aquela que transforma um casamento em batalha (em vida) e uma batalha em casamento (na morte). Dela nasce a possibilidade de ler os pares Pirítoo-Hipodâmia e CílaroHilonômia como reflexos um do outro, pois representam a imagem grotesca por excelência (que não deixa de ser também monstruosa), conforme a caracteriza Bakhtin: ${ }^{37}$ a da renovação a partir da degradação, do ressurgimento a partir da

\footnotetext{
${ }^{35}$ Cf. Debrouhun, op. cit.

${ }^{36}$ Cf. Bakhtin, op. cit., p. 2.

${ }^{37}$ Cf. Bakhtin, op. cit.
} 
destruição, enfim, de uma nova vida a partir da morte.

\section{Conclusão}

Após procedermos ao entrecruzamento dos domínios do grotesco e do monstruoso e constatarmos tantas imbricações entre eles, percebemos quanta contribuição a sua reunião é capaz de trazer para a análise de determinadas obras da Antiguidade ou de determinadas entidades mitológicas não-canônicas (no sentido tradicional do termo). As figuras que aqui foram tematizadas, como as de sátiros e centauros, espíritos rústicos e selvagens da Natureza, podem ser perfeitamente classificadas como monstruosas ou grotescas. Vários são os fatores que corroboram essa possibilidade de classificação, tais quais seu hibridismo estruturante, que por sua vez gera a indefinição de seu comportamento; sua tendência à desmedida, à transgressão de quaisquer limites e, pois, de se situar sempre em um espaço fronteiriço; sua representação por imagens hiperbólicas que, por vezes, atingem o ridículo, provocando a comicidade. O próprio Bakhtin ${ }^{38}$ cita exatamente os sátiros e centauros, entre outros, como exemplos de "seres extraordinários", "meio homens e meio bestas", "todos de caráter grotesco", compondo "uma verdadeira galeria de imagens do corpo híbrido". 39

No que concerne às obras que aqui serviram de objeto de estudo, tanto elas encerram figurações grotescas e monstruosas quanto elas próprias podem ser consideradas reproduções desse gênero. Com efeito, o Ciclope de Eurípides, bem como o episódio em destaque das Metamorfoses de Ovídio, constituem textos híbridos antes de tudo, pois mesclam desde o estilo de linguagem ao gênero. $O$ drama grego, transitando entre a Comédia e a Tragédia (como é comum a todo drama satírico), deixa rastros de um discurso baixo (típico dos sátiros) e de outro elevado (típico de um herói como Odisseu), além dos demais aspectos grotescos anteriormente discutidos. O quadro da Centauromaquia retirado da obra latina, por sua vez, transita entre a Epopeia e a Lírica questionando a própria genuinidade de seus discursos. Portanto, ambos os textos admitem ser lidos e entendidos sob uma mesma ótica do grotesco e do monstruoso.

Por fim, rememorando os sentidos que os gregos e latinos antigos atribuíam aos termos correlatos Tépas e monstrum, o maior monstro que podemos apreender dessas duas obras não é nem completamente um prodígio, nem apenas um ser disforme ou fantasioso nem fenômeno exclusivamente cruel ou terrível: é um ser que não se encaixa

\footnotetext{
${ }^{38}$ Cf. Bakhtin, op. cit., p. 302-303.
}

${ }^{39}$ Grifo do autor. 
exatamente em nenhuma dessas categorias, mas antes vagueia entre todas elas. Trata-se, afinal, em última instância, da representação do próprio homem, que por vezes possui, sob sua aparência humana, algo de animalesco, heroico ou mesmo divino. E assim, pode ser retratado em seus impulsos mais vis, que beiram a exageração e o ridículo, tornandose cômico, ou em suas aspirações mais dignas e atitudes mais nobres, que visam o sublime.

\section{Referências}

AQUATI, C. O grotesco. In: O grotesco no Satíricon. São Paulo: FFLCHUSP, 1997, p. 18-45 (tese de doutorado em letras clássicas).

BAILLY, A. Dictionnaire Grec-Français. Paris: Hachette, 1950.

BAKHTIN, M. A cultura popular na Idade Média e no Renascimento. O contexto de François Rabelais. Tradução de Yara Frateschi Vieira. São Paulo: Hucitec, 2008. Brill'S New Pauly. Encyclopedia of the ancient world. Boston: Leiden, 2007. Vols. IV/ $\mathrm{V} / \mathrm{X}$.

CLAY, J. S. Hybrids. In: Hesiod's cosmos. Cambridge: University Press, 2006, p. 150-174.

COHEN, J. J. A cultura dos monstros: sete teses. In: da SILVA, T. T. (org.). Pedagogia dos monstros. Os prazeres e os perigos da confusão de fronteiras. Belo Horizonte: Autêntica, 2000, p. 25-60.

DEBROHUN, J. B. Centaurs in love and war. Cyllarus and Hylonome in Ovid "Metamorphoses" 12.393-428. American journal of philology. Baltimore, vol. CXXV, n. 3, p. 417-452, 2004 (disponível em: <http://muse.jhu.edu> acesso em 30 de setembro de 2008).

ERNOUT, A.; MEILLET, A. Dictionnaire étymologique de la langue latine. Paris: Klincksieck, 2001.

EURIPIDE. Le Cyclope. Texte ét. et trad. par Louis Méridier. Paris: Les Belles Lettres, 1947. Tome I.

The Cyclops. Edited by D. M. Simmonds and R. R. Timberlake. London: Bristol Classical Press, 1997.

EURÍPIDES; ARISTÓFANES. Um drama satírico e duas comédias. Tradução de 
Junito de Souza Brandão. Rio de Janeiro: Espaço e Tempo, 1987.

FANTAHAM, E. Fantasy, the fabulous and the miraculous: metamorphoses of nature. In: Ovid's “Metamorphoses”. Oxford: University Press, 2004, p. 105-118.

FLETCHER, J. Perjury and the perversion of language in Euripides' "Cyclops". In: HARRISON, G. W. M. (org.). Satyr drama. Tragedy at play. Swansea: The Classical Press of Wales, 2005, p. 53-66.

GRIMAL, P. Dicionário da mitologia grega e romana. Tradução de Victor Jabouille. Rio de Janeiro: Bertrand Brasil, 1993.

Lexicon Iconographicum Mythologiae Classicae (LIMC). Zürich/ München: Artemis Verlag Zürich, 1981. Vol. VIII, 2.

MUSGROVE, M. W. Nestor's Centauromachy and the deceptive voice of poetic memory (Ovid Met. 12.182-535). Classical philology. Chicago, vol. XCIII, n. 3, p. 223 231 (disponível em: <http://www.jstor.org/stable/270542> acesso em 30 de setembro de 2008).

OVIDE. Les Métamorphoses. Texte établi et traduit par Georges Lafaye. Paris: Les Belles Lettres, 1957. Tomes I/ III.

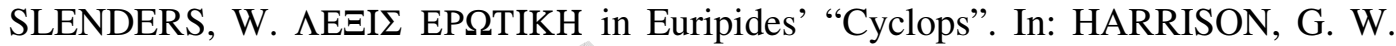
M. (org.). Satyr drama. Tragedy at play. Swansea: The Classical Press of Wales, 2005. p. 39-52.

SUTTON, D. The satyr play. A preliminary sketch. In: Meisenheim am Glan: Hain, 1980, p. 134-145. . Greek satyr play.

VOELKE, P. Formes et fonctions du risible dans le drame satyrique. In: DESCLOS, M.-L. (org.). Le rire des grecs. Anthropologie du rire en Grèce ancienne. Grenoble: Jérôme Millon, 2000, p. 95-108. 